\title{
The Effect of Sales Promotion and Product Quality on Repurchase Intention at Restaurant of Brottus Fried Chicken Kupang
}

\author{
Yefta Sanam, Margaretha Sartien K \\ \{yeftasanam@gmail.com, titinkabanga@gmail.com\} \\ Administration and Business Department, State Polytechnic of Kupang East Nusa Tenggara
}

\begin{abstract}
Consumer repurchase intention is very important for companies that want to extend the viability of their business and reap the success of their business in the form of long-term profits. Therefore, the purpose of this research is to find out how the effect of sales promotion and product quality on repurchase intention in Brottus Fried Chicken Restaurant. This research was conducted by survey method in which the population is all consumers who make repeat purchases at Brottus Fried Chicken Restaurant. The number of samples used was 96 people taken by the non-probability sampling method, using accidental sampling technique. Data were collected using a questionnaire and processed by multiple regression analysis. The research findings show that product quality has a positive and significant effect on consumer repurchase intention in Brottus Fried Chicken Restaurants, while sales promotion has no significant effect on consumer repurchase intention.
\end{abstract}

Keywords: sales promotion, product quality, repurchase intention.

\section{Introduction}

The development of technology has resulted in changes in people's lives. The community becomes easier and faster in getting references / information. The nature of the people who do not want to miss the trend has triggered the development of the business sector in all aspects. One business that is developing is in the culinary business. Every year the culinary business becomes a business field that attracts many people, because the profits or profits are large, and do not need to use large capital. In addition, food is a basic necessity for everyone so that culinary business opportunities are still very open. One of the culinary business that is currently growing rapidly is in businesses that provide fast food. According to data from the Kupang Central Statistics Agency (BPS) [1], it is known that the development of the number of restaurants / restaurants has increased significantly from 1,262 in 2016 to 1,416 restaurants / restaurants. With such developments it is certain that there is a buying interest of consumers in the restaurant business.

Interest in repurchase by consumers is a desire that arises to make repurchases on the same product / service because of the satisfaction he had felt. According to Peter and Olson [2], interest in repurchase is a purchase activity carried out more than once or several times. Many factors affect consumer repurchase intention, including sales promotion and product quality [3]. Promotion is an important factor in realizing the sales goals of a company, because after all good business if not known by consumers will not produce a transaction / purchase. 
Promotions that are often used to increase consumer purchases quickly in the short term include using sales promotions. The effect of good promotion (conveying the superiority of the product) can attract consumer buying interest and foster consumer buying priorities and consumer repurchases. Repurchase intention is also influenced by the quality given to consumers. According [1] product quality is a characteristic of a product or service that depends on its ability to satisfy the stated or implied customer needs. Product quality is an added value from every aspect related to products needed by consumers, so consumers who are satisfied with the quality of the products they feel will be interested in making a repeat purchase.

One of the businesses in the city of Kupang that relies on product quality, and promotion is the processed chicken business. This business is currently growing rapidly in urban areas that offer a variety of menu choices and flavors. In this research, the object to be investigated is the Brottus Fried Chicken Restaurant, where this business is the first pioneer of Geprek Chicken in the city of Kupang and a container restaurant in the city of Kupang. The main products of this restaurant are Ayam Geprek Brotus and Ayam Boleyyo. This restaurant also applies membership to Brottus Fried Chicken customers to increase customer loyalty. Consumer repurchase intention is very important for companies that want to extend the viability of their business and reap the success of their business in the form of long-term profits. The aim of this research is to find out the effect of sales promotion and product quality on repurchase intention in Brottus Fried Chicken restaurant.

\section{Literature Review}

Triastuti and Ferdinand in their research, the aim of this research was to determine the effect of service quality, product quality and sales promotion on consumer repurchase intentions [4]. The research was conducted on 75 respondents who are consumers of the Koffee + Jazz Semarang Bouquet. The results showed that the quality of service, product quality and sales promotion influence the consumer's buying interest in Buket Koffe + Jazz Semarang. This research provides information that service quality, product quality and sales promotion contribute to the variable repurchase intention of $33.4 \%$, while the remaining $66.6 \%$ is influenced by other factors not examined in this research, so it is necessary to conduct further research on other factors that influence consumer repurchase intention.

[5] discusses product quality, price and buying interest. The results of his research showed that product quality and price had a significant influence on speedy buying interest at PT. Telkom, Tbk Indonesia partially West Jabab Sukabumi Witel. Further research shows that product quality, service quality and sales promotion variables partially and simultaneously have a significant effect on repurchase intention [6]. The dominant influential variable is sales promotion. Likewise, the results of [7] research showed that there was a positive influence on sales promotion, experiential marketing, product quality and service quality on repurchase intention in the Yogyakarta Geprek Sa'I chicken restaurant.

[8] in their research findings show that the preference of sales promotion techniques will have an impact on consumer buying interest for all types of products studied. On the other hand, there is no significant impact on the effect of sales promotion on consumer buying interest for certain types of products studied. 


\section{Research Methods}

Research is included in the type of causal research, where this research is to identify the causal relationship between variables. This research took place at the Kupang Fried Chicken Brottus Restaurant. The subjects in this research were consumers who had made purchases at the Kupang Fried Chicken Brottus Restaurant. Because the amount of population taken is large and the amount is not known with certainty, so the formula below is used [3] :

$$
\mathbf{N}=\frac{\mathbf{Z}^{2}}{\mathbf{4 ( m o e})^{2}}
$$

So based on the formula above 96 samples can be taken. The sampling method used in this research is non probability sampling, using accidental sampling technique. The research tool used in this research was a questionnaire. In this research, each respondent's opinion and statements in the questionnaire were rated on a semantic differential scale.

\section{Research Findings}

\subsection{Data Analysis}

The classic assumption test in multiple linear regression analysis is needed to find out which variables meet and do not meet the classical assumptions. The first classic assumption test is the normality test conducted on each research variable to find out which variables meet and do not meet the normality assumption (these variables are normally distributed). Normality test is carried out by graph analysis (normal probability plot) which will be presented in the following figure:

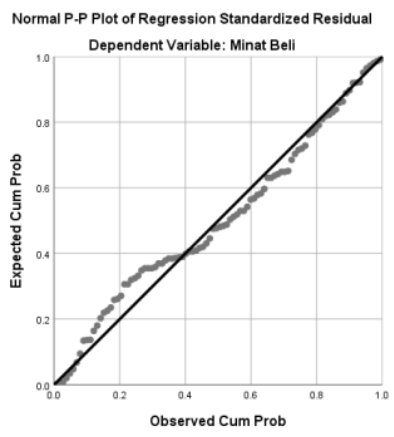

Fig. 1. Normal P-P Plot.

Based on normal P-P plot images in research related to the effect of sales promotion and product quality on repurchase intention in Brottus Fried Chicken restaurants, it appears that the data has been normally distributed. Judging from the points that spread along the diagonal line.

The next classic assumption test is the multicollinearity test, where this test aims to determine whether the independent variables are linearly related. Multicollinity testing is done 
by looking at the value of VIF and tolerance. The results of the analysis of multicollinearity can be seen in the following table:

Table 1. Results of Multicollinearity.

\begin{tabular}{ccc}
\hline Variable & Tolerance & VIF \\
\hline Promotion & 0.642 & 1.557 \\
Quality & 0.642 & 1.557 \\
\hline
\end{tabular}

An indication of multicollinearity is when the VIF limit is 10 and tolerance is 0.10 . If the VIF value is greater than 10 and tolerance is less than 0.100 then multicollinearity occurs. From the analysis it can be seen that all independent variables of sales promotion and product quality on repurchase intention in Brottus Fried Chicken Restaurant are free from multicollinearity problems.

To achieve the research objectives, multiple linear regression statistical analysis is used. This statistical analysis is used to answer the problems raised, namely to determine the effect of sales promotion variables and product quality both partially and simultaneously repurchase intention in Brottus Fried Chicken Restaurant, so that the regression equation is obtained as follows:

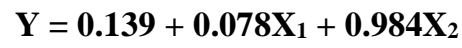

Then the calculation results presented in the table above can be explained that the constant value in the equation is 0.139 . This means that if the variable of sales promotion and product quality is considered constant, then the value of repurchase intention in Brottus Fried Chicken Restaurant is 0.139 , which means that consumer repurchase intention is stated to be very low or very uninterested, because the constant value is smaller than the scale semantic differential ranging from 1 (one) to 7 (seven).

Table 2. Results of Multiple Linear Regression Analysis.

\begin{tabular}{|c|c|c|c|c|c|c|}
\hline & \multirow[t]{2}{*}{ Model } & \multicolumn{2}{|c|}{ Unstandardized Coefficients } & \multirow{2}{*}{$\begin{array}{c}\text { Standardized } \\
\text { Coefficients } \\
\text { Beta }\end{array}$} & \multirow[t]{2}{*}{$t$} & \multirow[t]{2}{*}{ Sig. } \\
\hline & & $B$ & Std. Error & & & \\
\hline \multirow{3}{*}{1} & (Constant) & 0.139 & 0.387 & & 0.359 & 0.720 \\
\hline & Promotion & 0.078 & 0.087 & 0.063 & 0.902 & 0.370 \\
\hline & Quality & 0.984 & 0.085 & 0.803 & 11.511 & 0.000 \\
\hline
\end{tabular}

The effect of sales promotion variables on consumer repurchase intention with the SPSS program, then the regression coefficient value of 0.078 was obtained. This means that for every increase in sales promotion variable by 1 unit, it will increase consumer repurchase intention in the Brottus Fried Chicken Restaurant by 0.078 units assuming the other variables are fixed. In other words, if there is an increase of 100 percent in the variable sales promotion can increase consumer repurchase intention by 7.80 percent, and vice versa if there is a decrease in sales promotion variables can reduce consumer repurchase intention in Brottus Fried Chicken Restaurant.

The influence of product quality variables on consumer repurchase intention obtained a regression coefficient of 0.984 . This means that for every increase in product quality variables by 100 percent can increase consumer repurchase intention by 98.40 percent, and vice versa if 
there is a decrease in product quality variables can reduce consumer repurchase intention. If related to the theory of the effect of product quality on repurchase intention that has a positive direction, then in this research it can be seen that product quality has a direct effect on consumer repurchase intention.

Table 3. Determination Coefficient Test Results.

\begin{tabular}{ccrrr}
\hline Model & $R$ & $R$ Square & Adjusted $R$ Square & $\begin{array}{c}\text { Std. Error of the } \\
\text { Estimate }\end{array}$ \\
\hline 1 & 0.842 & 0.709 & 0.703 & 0.46046 \\
\hline
\end{tabular}

The coefficient of multiple determination $\left(\mathrm{R}^{2}\right)$ obtained a value of 0.709 or 70.90 percent. Furthermore, an adjusted $\mathrm{R}^{2}$ value of 0.703 is obtained, this means that the degree of influence of each of the sales promotion variables and product quality is able to shape consumer repurchase intention of 70.30 percent. While the remaining 29.70 percent is caused by other variables beyond the scope of the research.

Table 4. F Test Results (Anova Test).

\begin{tabular}{|c|c|c|c|c|c|c|}
\hline & Model & $\begin{array}{c}\text { Sum of } \\
\text { Squares }\end{array}$ & $d f$ & $\begin{array}{c}\text { Mean } \\
\text { Square } \\
\end{array}$ & $F$ & Sig. \\
\hline \multirow{3}{*}{1} & Regression & 48.104 & 2 & 24.052 & 113.442 & 0.000 \\
\hline & Residual & 19.718 & 93 & 0.212 & & \\
\hline & Total & 67.822 & 95 & & & \\
\hline
\end{tabular}

The known $\mathrm{F}$ count is 113.442 with a significant level of 0.000 . When compared with $\mathrm{F}$ the table is determined based on a table with a significant level of 5 percent and df $1=(\mathrm{k}-1)=2$ and $\mathrm{df} 2=(\mathrm{n}-\mathrm{k})=93$, so that the $\mathrm{F}$ table value of 2.320 is obtained. Because the value of Fcount is greater than Ftable $(113.444>2.320)$ then $\mathrm{H}_{0}$ is rejected and $\mathrm{Ha}$ is accepted. This means that simultaneously sales promotion and product quality variables have a significant influence on consumers' repurchase intention in Brottus Fried Chicken Restaurants.

The level of significance of the variable sales promotion on consumer repurchase intention of the Brottus Fried Chicken restaurant obtained data calculation results with SPSS that $t$ count for the variable sales promotion is equal to 0.902 with a significant value of 0.370 . If the $t$ value is 0.902 compared to the $t$ table value of 1.985 , then the $t$ value is smaller than $t$ table which means $\mathrm{HO}$ is accepted and $\mathrm{Ha}$ is rejected. This can also be seen from the comparison value between the significant values achieved of 0.370 which means an error rate greater than 5 percent. Thus the sales promotion variable has a positive and not significant effect on consumers' repurchase intention in Brottus Fried Chicken Restaurant.

The level of significance of product quality variables on consumer repurchase intention of Brottus Fried Chicken restaurants shows that the $t$ count for the product quality variable is 11.511 with a significant value of 0.000 . If the value of $t$ arithmetic is 11.511 compared to the value of $t$ table of 1.985 , then the value of $t$ arithmetic is greater than $t$ table which means H0 is rejected and $\mathrm{Ha}$ is accepted. This can also be seen from the comparison value between the significant values achieved at 0.000 which means the error rate is less than 5 percent. Thus the product quality variable has a positive and significant effect on consumers' repurchase intention of the Brottus Fried Chicken Restaurant. 


\subsection{Discussion}

From the test results it can be proven that the sales promotion and product quality affect the buying interest of consumers at the Brottus Fried Chicken Restaurant together. Consumer buying interest is a consumer behavior where consumers have the desire to choose, use, and consume or even want a product offered. Purchasing interest in this research is influenced by two factors including sales promotion and product quality. The results of this research are relevant to previous studies conducted [4], [6], and [7], where the results of his research stated that there was a positive influence on sales promotion and product quality on repurchase intention.

Consumer buying interest can be influenced by promotions, promotions carried out by various methods will be a way to attract the attention of consumers. Then it will attract consumers to buy the products offered. Consumer buying interest can also be influenced by product quality, because consumers in choosing a product will consider the quality indicators of the product. Good quality products will certainly affect consumer buying interest. Sales promotion and product quality can influence consumer buying interest together in this research. The results of multiple regression analysis showed a coefficient of determination of 0.703 . This means that the two independent variables (sales promotion and product quality) are able to explain 70.30 percent change in the dependent variable repurchase intention, while the other 29.70 percent is influenced by other variables not mentioned in this research. This explains that there are still other factors that influence consumers in buying a product that is not mentioned in this research.

The results of this research indicate that there is a positive relationship between sales promotion and repurchase intention, because when respondents were asked about the impact of sales promotion on their repurchase intention, most respondents responded that promotional activities motivated them to repurchase. They often make purchases when they see promotional activities in the form of advertising through social media such as Facebook and Instagram. Even when they do not have the intention to buy, but when they see a promo done through Android and iOS applications such as Go-Food and Grab Food, respondents become more motivated to make repeat purchases.

Appropriate sales promotion will increase consumer buying interest [9]. Sales promotions are used to support a variety of existing marketing strategies. Sales promotions carried out by various methods will be a way to attract the attention of consumers. Then it will attract consumers to buy the products offered. The more attractive the sales promotion, the higher the interest in repurchasing consumers. [9] added, the promotion mix is the best combination of strategies from the variables of advertising, personal selling, and other promotional tools, all of which are to achieve the sales program.

The results of this research are not relevant to previous studies conducted by [4], [6], [7] which states that there is a positive influence on sales promotion on repurchase intention. However, sales promotions are subject to a small research in which almost everything is written in the handbook as a sales promotion guide sourced from the United States. There is too much concentration on the American market so that the consumer perspective regarding sales promotion applications in other regions becomes insignificant [8]. In addition, most of the research conducted on sales promotions is related to the concentration on the use of monetary promotions (promotion costs), where little research is done on the aspect of nonmonetary promotion and also focuses on the Asian market.

The cultural context proved important to consider in research on buying interest. People who come from more collectivistic countries seem to experience stronger pressure from other 
important people and are more willing to obey their opinions. On the other hand, individuals born and raised in individualistic countries actually have stronger attitudes toward certain behaviors and pay less attention to what others think or do. Therefore, it has been suggested by many experts that the preference of different sales promotion techniques will lead to the level of purchase satisfaction and good buying interest behavior [8].

Previous research [5] supports this research, that promotion is not significant in influencing consumer repurchase intention. The results of his research showed that sales promotion did not have a significant impact on Speedy's buying interest at PT Telkom Tbk Indonesia Witel South Jabar Sukabumi. Likewise, [8] who examined the behavior of Malaysian consumers in which their buying patterns showed the most widely used and preferred sales promotion techniques were coupons, price discounts, free samples and bonus packages. Malaysian consumers tend to feel ashamed to enjoy cost-effective promotional offers. This happens because they see this promotional offer as an opportunity to purchase more products that are worth buying. It is different compared to Japan, where they see it as a sign of poverty even though the two countries are categorized as collectivist countries but with the same sales promotion strategy, the results will be different in each region.

The results of this research indicate that the product quality variable has a positive and significant effect on consumers' repurchase intention in the Brottus Fried Chicken Restaurant. The better the quality of the product, the higher the interest in repurchasing consumers at the Fried Chicken Brottus Restaurant. Consumers in making purchases always consider matters relating to the quality of the product to be purchased. Product quality is considered important by consumers and is used as the basis for decision making.

\section{Conclusion and Suggestions}

Based on the data analysis done in the previous chapter, it can be concluded that the variables of sales promotion and product quality simultaneously have a significant effect on consumer repurchase intention in Brottus Fried Chicken Restaurant. Partially only the product quality variable has a positive and significant influence on consumer repurchase intention, while the sales promotion variable has no significant effect on consumer repurchase intention.

Suggestions can be made to the manager of the Brottus Fried Chicken Restaurant to give greater attention and focus on the variable sales promotion, because these variables are not able to make a significant contribution in influencing consumer repurchase intention. This research is inseparable from the limitations and weaknesses, including the location of only one object only (Brottus Fried Chicken Restaurant), so the results of the research cannot be generalized to a wider area.

\section{References}

[1] BPS Kota Kupang: Jumlah Restoran dan Rumah Makan di Kota Kupang Tahun 2016 - 2017. Badan Pusat Statistik, Kupang (2018)

[2] Pratama, G.G.F.S.: Pengaruh Atribut Produk dan Demografi Konsumen Terhadap Minat Beli Ulang Susu Pasteurisasi Indomilk. Tesis Pascasarjana Universitas Pasudan (2016)

[3] Kotler, P., dan Armstrong, G.: Prinsip-prinsip Pemasaran Jilid I Edisi 12. Erlangga, Jakarta (2008) 
[4] Triastuti, F.R.J., dan Ferdinand, A.T.: Analisis Pengaruh Kualitas Pelayanan, Kualitas Produk dan Promosi Penjualan Terhadap Minat Beli Ulang Konsumen Buket Koffee+Jazz Semarang. Skripsi Fakultas Ekonomi dan Bisnis Universitas Diponegoro (2012)

[5] Destyadi, A.R.: Pengaruh Kualitas Produk dan Harga Terhadap Minat Beli Speedy (Studi Kasus pada PT Telkom Indonesia Cabang Witel Jabar Selatan Sukabumi Januari-Desember 2014) (2015)

[6] Pratiwi, L.Y.: Analisis Pengaruh Kualitas Produk, Kualitas Layanan dan Promosi Penjualan Terhadap Minat Beli Ulang (Studi Kasus pada PT Veneta Nusantara Cabang Malang). Vol. 1, No. 2. Jurnal Riset Mahasiswa Manajemen (2013)

[7] Harfania, F.: Pengaruh Promosi Penjualan, Experiential Marketing, Kualitas Produk dan Kualitas Pelayanan Terhadap Minat Beli Ulang (Studi Kasus pada Restoran Ayam Geprek Sa'i Yogyakarta). pp. 581-591. Jurnal Fakultas Ekonomi Universitas Negeri Yogyakarta (2018)

[8] Weng, J.T., dan Run, E.C.: Consumers' Personal Values and Sales Promotion Preferences Effect on Behavioural Intention and Purchase Satisfaction for Consumer Product. Vol. 25, No. 1, pp. $70-$ 101. Asia Pacific Journal of Marketing and Logistics (2013)

[9] Swastha, B.D., dan Irawan: Manajemen Pemasaran. Gramedia Pustaka Utama, Jakarta (2011) 